\title{
Az ausztriai tanártovábbképzés helyzete a 21. század tízes éveiben
}

\author{
Nádudvari Gabriella
}

\author{
SZTE JGYPK Alkalmazott Egészségtudományi és Egészségfejlesztési \\ Intézet tanársegéde \\ nadudvari.gabriella.erika@szte.hu
}

\begin{abstract}
Jelen tanulmány célja, hogy kísérletet tegyen az ausztriai tanártovábbképzés helyzetének feltárására a 2010-es években zajló tanártovábbképzési reform tükrében. A tanulmány primer források elemzése során részletesen vizsgálja, milyen oktatáspolitikai célokat fogalmaztak meg, és mely kompetenciák fejlesztését irányozták elő a reformfolyamatot irányító és segítő szakemberek. A vizsgált időszakban megvalósult továbbképzések tartalmi, formai aspektusairól, a minőségbiztositás módjáról és a még megoldásra váró problémákról a tanártovábbképzésekre reflektáló szekunder források eredményeit bemutató rész számol be.
\end{abstract}

Kulcsszavak: Ausztria, tanártovábbképzés, a tanártovábbképzés reformja

DOI: 10.37205/TEL-hun.2020.1-2.02

\section{Bevezetés}

A tanártovábbképzés mint a tanárképzés harmadik fázisa ${ }^{1}$ fontos szerepet tölt be a tanárok szakmai fejlődésének folyamatában, hiszen a szakmaiság kialakulása és fejlődése nemcsak a viszonylag rövid ideig tartó képzési időre, hanem a szakma gyakorlásának akár négy évtizedet felölelő időszakára is kiterjed. Ezért nem véletlen, hogy a tanártovábbképzés tanári szakmai fejlődésre gyakorolt hatása a nemzetközi szakirodalomban népszerű téma, hiszen a multikulturalitás és a digitális világ által támasztott új kihívások, valamint a tanulók individuális fejlesztése iránti igény adekvát és hosszú távon is jól működő megoldásokat vár el a pedagógusoktól (Jaschke, 2016; Göb, 2017; Fischer, 2017).

\footnotetext{
${ }^{1}$ A bolognai rendszer szerint múködő osztrák tanárképzés első fázisa a BA-képzés, melynek keretében a hallgatók megszerzik a pedagógus szakmához szükséges alapkompetenciákat, és a pedagógia egy bizonyos területén képesítést szereznek. A második, egy évig tartó (indukciós) fázisban a BA végzettséggel rendelkező tanárok tanítanak, miközben mentorok kísérik figyelemmel a munkájukat. Ezt a szakmai gyakorlatot végezhetik közvetlenül a BA tanulmányaik után, és elismertethetik gyakorlatként a mesterképzésben (MA). A második fázis sikeres elvégzése után lehet részt venni különböző továbbképzéseken.
} 
Az utóbbi években Ausztriában is viszonylag élénk érdeklődés tapasztalható a kutatók körében a tanártovábbképzés iránt (Andreitz, Müller \& Wieser, 2017; Rechnungshof, 2017; Zehetmeier, 2017, 2019; Müller \& Andreitz, 2019; Müller, Kemethofer, Andreitz, Nachbaur \& Soukup-Altrichter, 2019). A vonatkozó primer és szekunder irodalom feltárása tanulságul szolgálhat számunkra abból a szempontból, hogy milyen felismerések alapján és milyen elvek mentén alakították ki a reformfolyamatot irányító és segítő szakemberek a továbbképzések kínálatát, valamint milyen területeken volna még szükség előrelépésre.

Jelen tanulmány az ausztriai tanártovábbképzés helyzetéről nyújt áttekintést a 2010-es években zajló tanártovábbképzési reformok céljainak és megvalósulásának tükrében. Külön hangsúlyt helyezünk a tanártovábbképzés kínálati oldalának jellemzőire, melyek a továbbképzéseken közvetített tartalmak hatékony felhasználására ösztönözhetik a résztvevőket, és így támogathatják a tanárok szakmai fejlődésének folyamatát is.

Tanulmányunk első részében rövid áttekintést nyújtunk az ausztriai tanárképzés főbb jellemzőiről. A második részben felvázoljuk az osztrák tanártovábbképzés helyzetét a tanártovábbképzési reformfolyamatot közvetlenül megelőző időszakban. A harmadik részben az Oktatási, Tudományos és Kutatási Minisztérium (Bundesministerium Bildung, Wissenschaft und Forschung) honlapján hozzáférhető, az Oktatási, Művészeti és Kulturális Minisztérium (Bundesministerium für Unterricht, Kunst und Kultur) 2009-es és az Oktatásért és Nőkért Felelős Minisztérium (Bundesministerium für Bildung und Frauen) 2014-es, a pedagógus-továbbképzésre vonatkozó körleveleit és azok mellékleteit összehasonlítva azt kutatjuk, milyen célokat tüztek ki, és milyen kompetenciák fejlesztését tartották fontosnak a reformfolyamatot irányító szakemberek. A negyedik részben a vonatkozó szakirodalmi források alapján feltárjuk, mely területeken érzékelhetők a reformkezdeményezések hatásai, és milyen változtatásokat tartana még fontosnak a szakma. Az ötödik rész a magyarországi gyakorlat számára fontos tanulságokat foglalja össze.

\section{Az osztrák tanárképzés jellemzői}

Az osztrák tanárképzés duális rendszerben müködik, így annak alapján tesznek különbséget a tanárok között, hogy milyen intézményekben folytatták tanulmányaikat. A pedagógiai főiskolákon (pädagogische Hochschule) azokat a tanárokat képzik, akik a magyar általános iskola alsó és felső tagozatának megfelelő iskola- 
típusokban (Volksschule, Hauptschule) végezhetnek pedagógiai tevékenységet. Ugyancsak a pedagógiai főiskolák feladata azon tanárok képzése, akik a kisegítő iskolákban (Sonderschule) és az egyéves, műszaki ismereteket közvetítő iskolákban (polytechnische Schule) tevékenykednek. A középiskolai szintű intézménytípusokban (AHS-Unterstufe/-Oberstufe, BMS, BHS) tanító pedagógusok képzése az egyetemeken folyik (Virág, 2018).

A főiskolákon és az egyetemeken folyó tanárképzés között mind a tanulmányok, mind a pályaalkalmasság tekintetében jelentős különbségek figyelhetők meg. A két tanárképzést folytató intézmény közül csak a pedagógiai főiskolákon kell a jelentkezőknek pályaalkalmassági vizsgát tenniük. A Karintiai Pedagógiai Főiskolán (Pädagogische Hochschule Kärnten) például a Bachelor-szintű tanulmányokra való alkalmasság vizsgálata magában foglalja a tanári hivatás gyakorlásához szükséges személyes alkalmasság vizsgálatát, a német nyelv szóbeli és írásbeli ismeretének tesztelését, valamint az egyes szakok számára a tantervben megfogalmazott szakmai alkalmasság (például zenei-ritmikus, testi-motorikus képességek) vizsgálatát. Az eredmények elemzése és megvitatása a felvételizővel folytatott személyes beszélgetés keretében zajlik, amelyen pszichológus is részt vesz. Az egyetemeken a művészeti szakok, illetve a mozgással, sporttal kapcsolatos szakok kivételével nem kell a jelentkezőknek bizonyítaniuk pályaalkalmasságukat (Nyikos, 2011).

A pedagógiai főiskolákon legalább hat szemeszter a képzési ido, melynek során 180 kreditet szereznek a hallgatók, majd tanulmányaik befejezése után „Bachelor of Education" (BEd) végzettséggel kezdhetik el pedagógiai tevékenységüket. $\mathrm{Az}$ egyetemi képzés ideje legalább 9 szemeszter. Az első négy szemeszterben a választott szakterületük tárgyait tanulják a hallgatók, majd a következő öt szemeszter során módszertani ismereteiket bővítik. Az egyetemi tanulmányok 12 hetes iskolai gyakorlattal végződnek. Az egyetemi szintű tanárképzés osztatlan jellegéből következik, hogy a végzősök egyetemi oklevelet vesznek át, és „Magister” fokozatot szereznek. A tanárjelöltek az egyetem befejezése után egyéves iskolai gyakorlaton (Unterrichtspraktikum) vesznek részt, melynek során csökkentett óraszámban tanítanak, és egy vezetőtanár támogatását élvezhetik, miközben pedagógiai témájú szemináriumokat látogatnak. A pedagógiai főiskolán végzett hallgatók a tanulmányaik befejezése után közvetlenül elkezdenek tanítani (Virág, 2018). A tanároknak mind szakmai szinten, mind pedig didaktikai és pedagógiai szinten korszerű ismeretekkel kell rendelkezniük, ezért elengedhetetlenül fontos feladat volt 
a tanárképzés és a -továbbképzés közös koncepciójának kidolgozása (Nyikos, 2011).

\section{A tanártovábbképzés helyzete Ausztriában a 2010 óta zajló reformot megelőző időszakban}

Posch (2010) szerint az osztrák tanárképzést hosszú ideig a töredezettség jellemezte, ami nemcsak a képzés színvonalában, a tanárok fizetésében és elismertségében mutatkozott meg, hanem a tanártovábbképzésben is visszatükröződött (Mayr \& Neuweg, 2009). Az 1986-os oktatási törvényben (Schulunterrichtsgesetz) meghatározott kötelezettség ellenére, mely szerint minden tanárnak élnie kell a továbbképzési kínálattal, csak az általános műveltséget nyújtó „Pflichtschule”2 tanáraitól várták el, hogy évente 15 továbbképzési órát teljesítsenek (Posch, 2010).

2007 előtt a tanárok továbbképzését a pedagógiai intézetek végezték. A 2006ban elfogadott oktatási törvény rendelkezéseinek megfelelően a pedagógiai intézeteket összevonták a pedagógiai akadémiákkal. ${ }^{3}$ Az új intézménytípus a pedagógiai fôiskola ${ }^{4}$ elnevezést kapta, a tanárok továbbképzései azóta a pedagógiai főiskolákon folynak. Ausztriában azonban még a 2010-es évek első harmadában sem vezettek átfogó és teljes körủ nyilvántartást a tanártovábbképzésekről sem a minisztériumban, sem az iskolákban, így szinte lehetetlen differenciált képet kapni a képzések fajtáiról vagy esetleges egymásra épüléséről (Virág, 2013).

Mayr és Neuweg (2009) arról számol be, hogy az ausztriai tanárok továbbképzése személyes ügy volt, ami azt jelenti, hogy a továbbképzések tartalmának és formájának a megválasztását a tanárokra bízták, akik leginkább egyéni érdeklődésük alapján választották ki a rendezvényeket. Annak kapcsán, hogy az iskola vezetése mennyiben befolyásolta a tanárok ezirányú döntését, csak kevés empirikus kutatás született. Mayr és Müller (2010) szerint az iskolai vezetők jelentős része nem sorolta alapvető tevékenységei közé a továbbképzés menedzselését, illetve, miként a Számvevőszék (Rechnungshof, 2007) anyagában olvashatjuk, csak kevéssé volt rálátásuk a munkatársaik továbbképzési tevékenységeire.

\footnotetext{
${ }^{2} \mathrm{Az}$ általános műveltséget nyújtó, kötelező Pflichtschule Magyarországon az általános iskolának felel meg. ${ }^{3}$ A főiskolai jellegű képzést nyújtó pedagógiai akadémia 1962-től 2007-ig múködött Ausztriában. Ebben az intézményben folyt a Volksschule (Magyarországon az általános iskola alsó tagozata), a Hauptschule (Magyarországon az általános iskola felső tagozata) és a Sonderschule (kisegítő iskola) tanárainak képzése. ${ }^{4}$ A pedagógiai fóiskola az alapfokú oktatásban tanító tanárokat képezi, illetve a továbbképzések színhelye Ausztriában.
} 


\section{A 2010 utáni ausztriai tanártovábbképzési reformfolyamat főbb célkitűzései}

A 21. század tízes éveinek elején az osztrák tanárképzési rendszer és azzal együtt a továbbképzési rendszer az átalakulás fázisában volt. A megújulás koncepciójának kidolgozását szakértői csoport végezte a kilenc tartományból álló Ausztriában. Programjukban a pedagógusképzés rendszerének rugalmasabbá tételét, a szakmai előrehaladás és felemelkedés lehetőségét, a tanári szakma felértékelődését és a szakmai továbbképzés megalapozását helyezték előtérbe. Hangsúlyozták a tartományonkénti széttagoltság megszüntetésének fontosságát, és törekedtek a keretfeltételek kialakítására (Virág, 2013).

Ebben az időben más német nyelvü országokhoz hasonlóan Ausztriában is megerősödött az az elvárás, hogy a tanártovábbképzés egyfajta közvetítő szerepet töltsön be az oktatáspolitika és az iskola között. A reformfolyamatok egyik fő célja az volt, hogy a rendszerirányítás érdekeivel összhangban a továbbképzések főbb tartalmait központilag szabályozzák, és a továbbképzésekben részt vevő pedagógusok kompetenciáit célirányosan fejlesszék. Ettől az új koncepciótól azt remélték, hogy a reformelképzelések (például az új érettségi vizsga, az oktatási standardok bevezetése) sokkal gyorsabban és hatékonyabban valósulnak meg (Müller \& Andreitz, 2019).

$\mathrm{Az}$ új rendszerben az illetékes minisztérium bizonyos tematikus súlypontok megjelölésével gyakorol befolyást az országos tanártovábbképzések tartalmára. Ezeket az előre meghatározott tartalmakat a tanártovábbképzési piac vezető szereplői, a pedagógiai főiskolák ajánlják fel. A pedagógiai főiskolák kapcsolatban állnak és egyeztetnek a különböző érdekcsoportokkal. A tanárok szolgálati viszonyát szabályozó 2013-as törvény (Landeslehrerdienstrechtgesetz) kimondja, hogy a pedagógus, bármely iskolatípusban is dolgozik, 15 továbbképzési órára kötelezhető (DN, 2013). Annak kapcsán, hogy e lehetőségből hogyan lesz kötelesség, illetve milyen hatással van ez a szabályozás a pedagógusok továbbképzési tevékenységére, pillanatnyilag nem áll rendelkezésre írásos formában rögzített információ.

Az osztrák Oktatási, Művészeti és Kulturális Minisztérium (Bundesministerium für Unterricht, Kunst und Kultur) 4/2009. számú, a 2010 és 2013 közötti időszakra vonatkozó körlevele, amelyet minden tartományi iskolai tanács (Landesschulrat) és minden pedagógiai főiskola rektori hivatala megkapott, már tartalmazza azokat a tematikus súlypontokat, amelyek megfelelnek a kormányprogramnak, és alátá- 
masztják a szakma reformtörekvéseit. A dokumentum célkitűzései közé tartozik rövid- és középtávon a továbbképzések minőségének, tartalmának, formájának, igényorientált jellegének optimalizálása és javítása. A körlevélhez mellékelt szakmai anyagban meglehetősen kevés, ám lényeges, a kormányzati szempontokat és a szakma által meghatározott projektek szemléletét visszatükröző aspektusra fókuszálnak a szakértők (BUKK, 2009).

Az Oktatásért és Nőkért Felelős Minisztérium (Bundesministerium für Bildung und Frauen) 2014-ben kiadott, a 2014-2018-as időszakra vonatkozó, 5/2014-es számú körlevele szerint a tanártovábbképzésnek lehetővé kell tennie és biztosítania kell a pedagógusok szakmai fejlődését, és támogatnia kell az iskolákban folyó oktatásfejlesztési folyamatokat. Meg kell felelnie a pedagógusok individuális igényeinek, valamint az iskolák és az oktatási rendszer innovációs követelményeinek és változásainak, egyensúlyt teremtve e területek között (BBF, 2014).

Az 5/2014-es számú körlevél az optimális hatásfok elérése céljából fontosnak tartja a továbbképzésekkel kapcsolatos tudományos eredmények bevonását a tervezési folyamatokba. A fókuszt a csapatszemléletre és az iskolán belüli struktúrákra kell helyezni, mindazonáltal támogatni kell a pedagógusok önálló, tanulói közösségekben és hálózatokban megvalósuló tanulását is. A képzésért felelős valamennyi félnek (pedagógiai főiskolák, tartományi iskolatanácsok, minisztérium), helyi szinten az iskoláknak, regionális szinten a tartományoknak és országos szinten a kijelölt felelős személyeknek együtt kell működniük (BBF, 2014). 
Az 1. táblázatban összefoglaljuk a 2010-től 2013-ig és a 2014-től 2018-ig terjedő időszak oktatáspolitikai célkitűzéseit:

\begin{tabular}{c}
\hline A 2010-2013-as időszakra vonatkozó \\
minisztériumi rendeletben \\
megfogalmazott célkitüzések \\
(BUKK, 2009)
\end{tabular}

az Új Középiskola (Neue Mittelschule) ${ }^{5}$

\section{A 2014-2018-as időszakra vonatkozó minisztériumi rendeletben megfogalmazott célkitűzések}

(BBF, 2014)

\section{az Új Középiskola (Neue Mittelschule)} fejlődésének nyomon követése

szakmai orientáció és képzési tanácsadás a szakmai és képzési út orientációja a képzési standard megvalósítása képzési standard és annak kompetenciaorientált oktatás keretében továbbfejlesztése

nyelvi sokszínűség, többnyelvűség, interkulturális tanulás

politikai képzés, demokráciára nevelés

erőszakprevenció/konfliktuskezelés

iskolai menedzsment, Leadership (több iskolai autonómia)

standardizált, új érettségi vizsga átfogó nyelvi fejlesztés minden korcsoportban (különösen az általános iskolában); nyelvi sokszínűség, többnyelvűség, interkulturalitás, nemzetköziesités

politikai képzés, demokráciára nevelés (a fiatalok felkészítse a társadalmi és a politikai életre) inkluzív oktatás minden képzési területen és minden iskolatípusban

szabadidőpedagógia az egésznapos iskolákban (sport- és mozgásorientált irány; egészlegesség-kreativitás támogatás) kompetenciaorientált oktatás minden korcsoportban; az alapkompetenciák közvetítése (különösen az alapszintű olvasás, írás és számolás terén)

iskolai menedzsment - a vezetők képzése a minőségbiztositás érdekében; iskola- és oktatásfejlesztés; eredménytudatosság standardizált és kompetenciaorientált érettségi és diploma (vizsga) mozgás és sport mint az iskolai hétköznapok állandó kísérője

\section{1. táblázat: Oktatáspolitikai célkitűzések a 2010-től 2013-ig} és a 2014-től 2018-ig terjedő időszakban ${ }^{6}$

\footnotetext{
${ }^{5}$ A képzési reform keretében az általános képzést nyújtó Hauptschulet (Magyarországon az általános iskola felső tagozata) fokozatosan felváltotta a Neue Mittelschule (Új Középiskola).

${ }^{6} \mathrm{~A}$ dőlt betűvel kiemelt szövegrészek a két vizsgált időszak oktatáspolitikai célkitűzései közötti különbségeket szemléltetik.
} 
A 2. táblázat összefoglalja a 2010-től 2013-ig és a 2014-től 2018-ig terjedő időszakra vonatkozó minisztériumi elképzeléseket az oktatáspolitikai célkitűzések elérése érdekében a tanártovábbképzések keretein belül fejlesztendő kompetenciákról:

\section{A 2010-2013-as időszakra vonatkozó minisztériumi rendeletben felsorolt kompetenciák}

tanári professzionalizáció

individuális bánásmód, differenciálás

gender kompetencia az IT pedagógiai és didaktikai alkalmazása médiakompetencia egészlegességre törekvő, kreatív tanulási kultúra az iskolában

\section{A 2014-2017-es időszakra vonatkozó minisztériumi rendeletben felsorolt kompetenciák}

tanári professzionalizáció

közvetítő, diagnosztizáló és fejlesztő kompetencia az individuális bánásmód, a differenciálás és a tehetséggondozás megvalósitása érdekében

az elektronikus médiumok pedagógiai és didaktikai bevezetése az oktatásba pedagógiai segítő és tanácsadói kompetencia (például tanulási design, tanulássegítés, mentorálás)

2. táblázat: Az oktatáspolitikai célkitűzések elérése érdekében fejlesztendő pedagógus kompetenciák ${ }^{7}$

A 2. táblázatból kitűnik, hogy a 2014-2017-es időszakban a főbb kompetenciák között új elemként szerepel a közvetítő, a diagnosztizáló és a fejlesztő kompetencia a tehetséggondozás megvalósítása érdekében. Ugyancsak új elemnek tekinthető, hogy a tanulássegítés kapcsán a pedagógiai segítő és tanácsadói kompetenciát helyezik előtérbe a szakemberek. Látható továbbá, hogy a 2010-2013-as időszakban kiemelten kezelt gender kompetenciának a 2014-2017-es időszakban már nem szentelnek figyelmet az oktatáspolitikai szakértők.

A fentebb felsorolt oktatáspolitikai célkitűzések és fejlesztendő pedagógusi kompetenciák tükröződnek a 2017. június 28-án elfogadott és 2017. szeptember 15-én közzétett, 5800 osztrák iskolát érintő oktatási reformban, amely az iskolák szabadságát, a rendszer átláthatóságát és modellrégiók létrehozását tűzte zászlajára az egységes iskoláért. Az Oktatási, Tudományos és Kutatási Minisztérium (Bundesministerium Bildung, Wissenschaft und Forschung) honlapján 2017-ben publikált tájékoztató anyag leszögezi: a tanulók különböző erősségekkel, tehetséggel és igényekkel vannak jelen a közoktatásban - minden gyermek és minden

${ }^{7}$ A dőlt betűvel kiemelt szövegrészek a két vizsgált időszak közötti különbségeket szemléltetik a fejlesztendő pedagógus kompetenciák szempontjából. 
iskolai közösség egyedi. Az iskolarendszernek meg kell felelnie ezeknek az eltérő követelményeknek és igényeknek. Ez csak akkor sikerülhet, ha a pedagógusok és az iskolák igazgatói nagyobb szabadsággal rendelkeznek. Mindemellett gondos minőségellenőrzésre van szükség, hogy a legjobb képzést nyújtsák a tanulóknak. Ezt az oktatás szisztematikus monitorizálásával és az iskolák külső értékelésével kell biztosítani egy egységes minőségbiztosítási keretrendszerben. Az oktatási reform céljai az alábbiakban foglalhatók össze:

- maximális pedagógiai mozgásszabadság,

- innovatív képzési kínálat kialakítása az egyes oktatási intézményekben (egyidejü tervezés- és forrásbiztosítás mellett),

- regionális képzési koncepciók lehetővé tétele, melyekben az iskolai profilok egymáshoz illeszthetők, és ily módon optimálisan megvalósítható az intézmények közötti átjárhatóság a tanulók számára,

- az iskolaigazgatók magas színvonalú képzése, az igényekhez igazodó, autonóm, az oktatási intézményekben megvalósuló tanártovábbképzések,

- célirányos minőségfejlesztés jobb minőségmenedzsmenttel és egységes oktatásellenőrzéssel (BBWF, 2017).

A fenti elemzés alapján megállapíthatjuk, hogy az oktatáspolitika az elmúlt évtizedben az egységes oktatási célok és az egységes kompetenciafejlesztés megvalósulásának érdekében központi irányításra törekszik, ugyanakkor - miként a dőlt betűvel kiemelt szövegrészből is kitűnik - kifejezésre juttatja az iskolai autonómia kiszélesítésére irányuló szándékát is.

Míg a reformot megelőző időszakban az iskolai vezetők nem tekintették alapvető feladatuknak a továbbképzések menedzselését, a 2017-es oktatási reform fó célkitűzéseinek egyike az iskolaigazgatók magas szintű képzése, ami hozzájárulhat a tanárok továbbképzésének iskolán belüli, összehangolt menedzseléséhez: az igények pontos feltárásához, megfogalmazásához és a lehetőségek megteremtéséhez. Az oktatási reformról szóló törvény 2017-ben módosított 34. cikkelyében olvasható 32. paragrafus 5 . bekezdéséhez hozzákapcsolt 6 . bekezdés már rendelkezik arról, hogy az iskola vezetésének minden tanárral rendszeresen, egyenként vagy kis csoportokban egyeztetnie kell a következő három év egyéni továbbképzési tervét. A beszélgetés tartalmát írásban kell rögzíteni, és a dokumentumot mind az iskola vezetésének, mind pedig a pedagógusnak alá kell írnia (BRG, 2017). E rendelet harmonizálhatja és átláthatóbbá teheti a tanártovábbképzésben zajló folyamatokat. 


\section{A 2010 utáni osztrák tanártovábbképzési reformfolyamatra reflektáló kutatások}

A tanártovábbképzés reformcélkitűzéseinek tükrében megállapíthatjuk, hogy a 2010-es években Ausztriában szemléletbeli fejlődés figyelhető meg a tanártovábbképzés terén. A továbbképzési gyakorlat differenciáltabbá vált: elmozdulás történt a hosszú távra tervezett, folyamatkísérő, kooperatív, szituatív, valamint problémaés igényorientált továbbképzés irányába, és az elméletalkotás terén is érzékelhető előrelépés (Fussangel, Rümp \& Gräsel, 2016 idézi Müller et al., 2019). Fejlődésről számol be Müller és Andreitz (2019) tanulmánya is, melyben az osztrák tanártovábbképzés jelene és jövője kerül górcső alá. A továbbképzések reformjának fő célja, hogy minden pedagógusnak lehetősége legyen az új kihívásokkal való könnyebb megküzdés érdekében a célirányos kompetenciák megszerzésére. Müller és Andreitz (2019) szerint 2013 után egyre inkább megerősödött az a tendencia, hogy a képzésekért, és így a tanártovábbképzésért is felelős minisztérium tartalmilag is irányítása alá vonja a tanártovábbképzést, hogy a széttagoltság megszüntetése érdekében többek között célirányos kompetenciák megszerzését tegye lehetővé a rendszer zavartalan működése érdekében. A pedagógiai főiskolák feladata a közvetítés a minisztérium által meghatározott tartalmak és a különböző érdekcsoportok által megfogalmazott tartalmi elvárások között. A kevés rendelkezésre álló adat tükrében azonban most még nehéz megítélni, hogyan működnek ezek az irányítási folyamatok.

Müller és munkatársai (2019) egy, a tanártovábbképzés keretfeltételeire, a továbbképzésekkel kapcsolatban megfogalmazott igényekre, a kínálatra, a formai és tartalmi aspektusokra, a minőségre, az aktuális trendekre és a tanártovábbképzés hatékonyságára reflektáló kutatási beszámolóban az osztrák tanártovábbképzési gyakorlat kritikus elemzésére vállalkoznak. ${ }^{8}$ Megállapítják, hogy az utóbbi években felszínre törő optimizmus ellenére e terület továbbra is alulreprezentált a pedagóguskutatás területén, és a szisztematikus értékelés, valamint a képzések dokumentációja továbbra sem megfelelő. A tanulmány szerzői egy jól strukturált, nyilvánosan is elérhető adatbázis létrehozását sürgetik.

\footnotetext{
${ }^{8}$ A szerzők kutatási beszámolójukban a Lehrerfort- und Lehrerweiterbildung (LFWB) gyüjtőfogalmat használják, de fontosnak tartják az e kifejezésben rejlő két fogalom közötti különbségtételt a német nyelvben. A két fogalom közötti alapvető különbség, hogy míg a Fortbildung a szakmai kompetenciák fejlesztését és az adott funkció keretein belüli kvalifikációt szolgálja, a Weiterbildung új funkciók betöltésére tesz képessé (például vezetői funkció, iskolakönyvtárosi munkakör, oktatásfejlesztői funkció). Mivel maguk a szerzők is kiemelik, hogy e két terület elkülönítése a gyakorlatban nem mindig történik meg, tanulmányunkban következetesen a tanártovábbképzés szót használjuk a német Lehrerfort- und Weiterbildung kifejezésére.
} 
A rendelkezésre álló kutatási eredményeket kiegészítendő, a szerzők 2018 tavaszán online írásbeli kikérdezést kezdeményeztek a pedagógiai főiskolákon, melynek keretében az alábbi aspektusokat vizsgálták: 1 . az egyes intézmények erősségei és gyenge pontjai, 2. formai (szervezeti struktúra) és tematikus trendek, 3. a keresleti oldal igényei, 4. példák a jó gyakorlatra, 5. értékelés és minőségmenedzsment, 6. továbbképzési tartalmak és innovációk, 7. a tudástranszfer gátló és támogató tényezői, 8. közép- és hosszútávú hatások, 9. kihívások. Minisztériumi engedéllyel feldolgozták a $\mathrm{PH}-O n \operatorname{line}^{9}$ információmenedzsment rendszerének 2015/2016-os tanévre vonatkozó adatait is. A kiértékelés során elemezték és kategorizálták az intézmények által felkínált továbbképzési tartalmakat, valamint megvizsgálták, milyen mértékben használták ki az osztrák tanárok a lehetőségeket. A kereslet-kínálat viszonyának elemzése mellett választ kerestek arra, hogy milyen vélemények fogalmazódtak meg az egyes továbbképzések időtartamáról, illetve milyen továbbképzési szerveződési formák azonosíthatók (Müller et al., 2019).

A 2015/2016-os tanévre, a tanártovábbképzéseken felkínált tartalmakra vonatkozó, a PH-Online-ból merített adatok vizsgálata során Müller és munkatársai (2019) a kategóriák egyértelmű elkülönítésére törekedtek. Megállapították, hogy az általuk felállított kategóriák közül a szaktárgyi képzés, az oktatás (módszerek, didaktika, reformpedagógia, új tanulási kultúrák stb.) és az általános pedagógiai témák (tanári szakmai fejlődés, általános pedagógiai kompetenciák) voltak a pedagógus-továbbképzés leggyakoribb témái. Ugyancsak magas gyakoriságot mutattak még a következő tartalmi kategóriák: kompetencia, teljesítménymérés, iskolai menedzsment, személyiségfejlesztés. Viszonylag kevés tanártovábbképzés foglalkozott az iskolai könyvtár, a biztonság és a kutatásmódszertan témakörével. A képzések közül a legmagasabb lemondási arány a kutatásmódszertan (24\%), a szociálpedagógia (22,7\%), a művészet és a kreatív tevékenységek $(22,5 \%)$ területén volt. Legkevesebben a szaktárgyi továbbképzéseket mondták le (9,2\%). A lemondások okai ismeretlenek (Müller et al., 2019).

A továbbképzések 75-90\%-a a minisztérium által előirányzott témakörökben valósult meg, a többi témát a pedagógiai főiskolák határozták meg az iskolákkal, valamint a tartományi és regionális szervekkel történt egyeztetések során (Müller et al., 2019).

\footnotetext{
${ }^{9}$ A PH-Online a pedagógiai főiskolák adatbankja, melyben a képzési és továbbképzési kínálatot dokumentálják, és melyet a pedagógiai főiskolák használnak.
} 
A rendezvények formáját tekintve öt típus különböztethető meg (Müller et al., 2019):

- országos és regionális szintű standard kínálat a legkülönbözőbb témákban,

- belső (iskolai) képzések, melyeken speciális, az iskola szempontjából releváns témákat dolgoznak fel,

- több iskola számára felkínált specifikus témák feldolgozása egy adott iskolában,

- föiskolai, egyetemi kurzusok,

- kutatói, fejlesztői projektekben való részvétel.

Müller és munkatársai (2019) vizsgálódásainak tanulságai szerint Ausztriában a 2015/2016-os tanévben leggyakrabban pedagógiai főiskolákhoz kapcsolódó, regionális rendezvényeket valósítottak meg, a kurzusoknak majdnem a fele ebbe a csoportba sorolható. A rendezvényeknek alig $2 \%$-a valósult meg online formában. Ebben az összefüggésben említhető meg egy, a Felső-Ausztriai Pedagógiai Főiskolán végzett kérdőíves kutatás, melyből kiderül, hogy a megkérdezettek 70\%-a egyáltalán nem vagy csak kevéssé tartja fontosnak az elektronikus platformokon való kommunikációt (Nachbauer, Weber \& Kemethofer, 2018 idézi Müller et al., 2019). ${ }^{10}$

Nachbaur és munkatársai (2018 idézi Müller et al., 2019) a továbbképzések időtartamára vonatkozó vizsgálatainak tanúsága szerint a kérdőívben felsorolt lehetőségek közül a félnapos rendezvényt a megkérdezettek 83\%-a, az egynapos továbbképzést a megkérdezettek $76 \%$-a választaná. Ezzel szemben a két- vagy háromnapos kurzust 45,9\%, a két-három fél- vagy egész napos rendezvényt $50 \%$ látogatná. (Minden válaszadó több, számára elfogadható lehetőséget is jelölhetett.) Lipowsky (2014) úgy véli, a továbbképzések időtartama fontos kérdés, hiszen a rövid továbbképzések nem alkalmasak a nehezen megváltoztatható kompetenciák fejlesztésére, mindazonáltal az időtartam szükséges, de nem elégséges hatékonysági tényező.

A magas színvonalon megvalósuló tanártovábbképzés egyik jó példája a FelsőAusztriai Pedagógiai Főiskola tanártovábbképzési struktúrája. Az intézmény kötelező és választható modulok kombinációjából álló továbbképzési kínálata megfelel a tanárok igényeinek, hiszen egyénileg választhatnak témákat és rendezvényeket, anélkül, hogy azonnal el kellene köteleződniük hosszú távra, mindazonáltal az el-

\footnotetext{
${ }^{10}$ A Nachbaur, Weber és Kemethofer (2018) által készített, nem publikált kutatási anyag az iskolaigazgatók és a tanárok körében végzett kikérdezés eredményeiről számol be (Nachbaur, Weber \& Kemethofer, 2018). Bedarfsanalyse für die Lehrerfortbildung in Oberösterreich 2014. Eine Befragung von Schulleitungen und Lehrer/innen aus Pflichtschulen. Unveröffentlichter Forschungsbericht. Linz: Pädagogische Hochschule Oberösterreich.
} 
mélyülés lehetősége is biztosított számukra. Az egy téma köré szerveződő továbbképzések hosszabb ideig tartanak, ami lehetővé teszi az input, a próba és a reflexiós fázis váltakozását, valamint a visszacsatolást és a tanárok közötti kommunikációt (Müller et al., 2019).

Az alábbi táblázat ennek a fent leírt tanárképzési koncepciónak a tipikus struktúráját mutatja be.

\begin{tabular}{|c|c|}
\hline $\begin{array}{l}\text { A továbbképzés oktatási } \\
\text { szakaszainak elnevezései }\end{array}$ & A továbbképzés oktatási szakaszainak tevékenységi körei \\
\hline $\begin{array}{l}\text { Bázismodul (16 oktatási } \\
\text { egység) })^{11}\end{array}$ & $\begin{array}{l}\text { A résztvevők bepillantást nyernek a különböző perspektívákat } \\
\text { ötvöző központi témába. E modult külön kurzusként vagy a } \\
\text { teljes képzés részeként is választhatják a résztvevők. }\end{array}$ \\
\hline $\begin{array}{l}\text { Választható modul - } \\
\text { elmélyülés ( } 65 \text { oktatási } \\
\text { egység): }\end{array}$ & $\begin{array}{l}\text { A résztvevők egyénileg választhatnak a továbbképzési } \\
\text { kínálatból a központi témához illeszkedő kurzusok közül. }\end{array}$ \\
\hline $\begin{array}{l}\text { Reflexiós modul (4 oktatási } \\
\text { egység) }\end{array}$ & $\begin{array}{l}\text { A résztvevők műhelymunka formájában megbeszélik a } \\
\text { különböző rendezvényeken szerzett ismereteket, és reflektálnak } \\
\text { a tanári hétköznapok kapcsán levonható konzekvenciákra. }\end{array}$ \\
\hline Dokumentáció & $\begin{array}{l}\text { A résztvevők dokumentálják ötleteiket és tapasztalataikat a } \\
\text { megszerzett tudás iskolai hétköznapokba történő átültetésével } \\
\text { kapcsolatban, valamint reflektálnak felismeréseikre. }\end{array}$ \\
\hline $\begin{array}{l}\text { Záró beszélgetés ( } 2 \text { oktatási } \\
\text { egység) }\end{array}$ & $\begin{array}{l}\text { A résztvevők egy záró tanácsadói beszélgetés keretében a } \\
\text { kurzus vezetőivel megvitatják az oktatásfejlesztéssel } \\
\text { kapcsolatban felmerülő ötleteket. }\end{array}$ \\
\hline $\begin{array}{l}\text { Zárórendezvény ( } 2 \text { oktatási } \\
\text { egység): }\end{array}$ & $\begin{array}{l}\text { A kurzus a felismerések prezentálásával és megbeszélésével } \\
\text { zárul. }\end{array}$ \\
\hline
\end{tabular}

3. táblázat: A Felső-Ausztriai Pedagógiai Főiskola továbbképzési sémája

A Felső-Ausztriai Pedagógiai Főiskolán az alábbi témakörökben szerezhető tanúsítvány: képzési „hidak” építése (az óvodából az iskolába történő átmenet megkönnyítésére); nyelvi képzés és többnyelvűség; önismeret és szociális kompetencia az együttélés kultúrájának fejlesztéséért, pedagógiai diagnosztika (Müller et al., 2019).

A minőségbiztosítás szempontjából az online kikérdezésben részt vevő mind a tizenegy pedagógiai főiskola a résztvevők értékelését és a visszajelzését tartja a legfontosabbnak (melynek fajtái: kérdőív, online kérdőív, interjú). Ugyanakkor a kutatásból az is kiderült, hogy a vizsgálat során e szempontból nyert információk meglehetősen heterogének.

\footnotetext{
${ }^{11}$ Az 1985-ös Oktatási Törvény (BgBl. Nr. 77/1985) tanítási időről szóló 4. § szerint egy oktatási egységnek 50 percig kell tartania. A 2017-ben elfogadott oktatási törvény célszerüségi és szervezési okokból lehetővé teszi az iskolaigazgatók számára, hogy a tanórák időtartamát a pedagógiai koncepciónak megfelelően csökkentsék vagy növeljék.
} 
A kutatásban részt vevő tizenegy pedagógiai főiskola közül három pedagógiai főiskolán minden képzés értékelése megtörtént. Egy pedagógiai főiskola a szemeszterenként felkínált rendezvényeknek legalább 50\%-át értékelte, ugyanakkor két pedagógiai főiskola csak néhány kiválasztott rendezvényt értékelt, míg öt pedagógiai főiskola nem adott meg adatokat. Négy pedagógiai főiskola egyértelmüen kifejezésre juttatta, hogy az értékelés eredményeit beépíti a későbbi tervezési folyamatokba, és késznek mutatkozik a következtetések levonására. Öt pedagógiai főiskola nyíltan megfogalmazta, hogy a résztvevők értékelése és a visszajelzése mellett a kínálat bővítését és tervezését ideális esetben az iskolákkal és/vagy az iskolafelügyeletekkel együtt történő tervezés, vagy akár egy nagyobb kerettervhez való alkalmazkodás is befolyásolja (Müller et al., 2019).

Bár a pedagógiai főiskolák rendezvényeiről alkotott vélemények konkrét eredményei nem elérhetők, néhány, a fentebb említett online kikérdezés során a pedagógiai főiskolákról érkezett, nem publikált dokumentumból az derül ki, hogy a résztvevők túlnyomórészt nagyon elégedettek vagy elégedettek voltak a továbbképzések általános minőségével, az időmenedzsmenttel, a képzők kompetenciájával, az infrastruktúrával és különösen a kollégák közötti kooperatív tapasztalatcsere lehetőségével. A résztvevők akkor tekintették sikeresnek a továbbképzéseket, ha konkrét módszertani, didaktikai tanácsokat kaptak, vagy jól hasznosítható anyagok, koncepciók birtokába jutottak, valamint lehetőségük volt saját személyiségük fejlesztésére (Müller et al., 2019). A résztvevők szubjektív visszajelzésein kívül kevés további adat áll rendelkezésre a tanárképzések hatékonyságát illetően (Andreitz et al., 2017; Zehetmeier, 2017).

Az online kutatásban részt vevő főiskolák egy része a jövőben kikerülhetetlen feladatnak és fontos kihívásnak tartja a képzési tartalmak iskolai gyakorlatba történő átültetését és ennek kutatását. Míg a megkérdezettek a tudás hasznosulásának biztosítékát többnyire a keretfeltételek javításában, a rendezvények koncepciójának folyamatos fejlesztésében, különösen a reflexiós és a kísérő transzferfázisok beépítésében látják, egy esetben azt fogalmazzák meg, hogy a továbbképzéseken megszerzett tudás iskolai környezetbe történő átültetése a tanár, az iskolavezetés, illetve a hivatalos szervek felelőssége (Müller et al., 2019).

Az osztrák oktatási rendszer még napjainkban is folyó átalakítása - például az iskolai autonómia erősítése miatt is - azt vonhatja maga után, hogy a jövőben az iskolák vezetői intenzívebb hatást gyakorolnak a pedagógusok továbbképzésekkel kapcsolatos döntéseire (Müller \& Andreitz, 2019). Ez azt is jelenti ugyanakkor, 
Pedagógusképzés • 19(47), 2020/1-2.

hogy a tanárok személyes érdeklődésének tiszteletben tartása mellett fontos kialakítani egy olyan szakmafelfogást, mely szerint a tanárnak nemcsak a saját oktatási tevékenységéért és önmagáért kell felelősséget vállalnia, hanem az iskoláért is, ahol dolgozik.

\section{A magyarországi gyakorlat számára fontos tanulságok}

Ebben a fejezetben a magyar tanártovábbképzési gyakorlat számára is hasznosítható tanulságokat foglaljuk össze. Hangsúlyozzuk a pedagógiai főiskolák szerepét a minisztérium és a különböző érdekcsoportok közötti közvetítésben, majd rávilágítunk, milyen elképzelések mentén kívánják az osztrák oktatáspolitikai szakértők élő, dinamikus rendszerré alakítani a tanártovábbképzést. Kiemeljük azokat a pedagógus kompetenciákat, amelyek fejlesztésére külön hangsúlyt fektet az osztrák oktatáspolitika. Figyelemreméltó tényként említjük továbbá, hogy a reformfolyamatokat irányító szakemberek a továbbképzésekkel kapcsolatos tudományos eredményeknek rendkívül fontos szerepet szánnak.

Ausztriában a 2010-es években zajló reformfolyamat során a tanártovábbképzésért is felelős minisztérium tartalmilag is irányítása alá vonta a tanártovábbképzést, hogy célirányos kompetenciák megszerzését tegye lehetővé a rendszer zavartalan múködése érdekében. A pedagógiai fóiskolák mint a továbbképzési piac vezető szereplői közvetítenek a minisztérium által meghatározott tartalmak és a különböző érdekcsoportok által megfogalmazott tartalmi elvárások között. Ausztriában felismerték, hogy a tanártovábbképzések nemcsak a reform keretében bevezetett új programok, képzési standardok megvalósulásában játszhatnak fontos szerepet, hanem azok továbbfejlesztésében is, amennyiben a tanártovábbképzés olyan élo, dinamikusan múködő rendszer, amely az egyensúly elvének értelmében nem pusztán felsőbb döntések végrehajtására törekszik, hanem autonóm, professzionális vezetői csapat által irányított oktatási intézmények szakmai, fejlesztési igényeinek a szolgálatát is célul tüzi ki.

Az oktatáspolitika külön hangsúlyt fektet arra, hogy az individuális bánásmód, a differenciálás és a tehetséggondozás érdekében a továbbképzések résztvevöi közvetító, diagnosztizáló, fejlesztő kompetenciákat sajátítsanak el, és képessé váljanak a tanulás segitésére és a mentorálásra. Az egyéni bánásmód, a differenciálás és a tehetséggondozás terén elvárt eredmények eléréséhez hozzájárul az iskolai autonómia kiszélesítése és a vezetőknek e folyamat kísérésére történő színvonalas felkészítése. 
Az optimális hatásfok elérése céljából a reformfolyamatokat irányító szakemberek kiemelt szerepet szánnak a továbbképzésekkel kapcsolatos tudományos eredményeknek. Ha a vizsgálódások fókuszát az individuális és az intézményi előfeltételek, a kereslet és a kínálat összeegyeztethetőségének lehetőségére, valamint az eredmények értékelésére helyezik, akkor a kutatásokból nyert információk nemcsak a tanártovábbképzések tartalmi és módszertani tervezése során válnak hasznosíthatóvá, hanem az alapkutatás szempontjából is fontosak lehetnek. Mindez természetesen akkor valósulhat meg, ha a továbbképzések dokumentációja egy jól strukturált, nyilvános adatbázis létrehozása révén elérhetővé válik a kutatók számára.

\section{Összegzés}

Jóllehet az utóbbi években Ausztriában valóban érzékelhető a trendváltozás, a tanártovábbképzés fejlesztése terén még mindig az egyik legnagyobb kihívásnak tủnik a probléma- és folyamatorientált, kooperatív, szituatív, valamint hosszú távú programok kimunkálása, melyek több tanítási egységből állnak, és a tanárok gyakorlati tevékenységét helyezik a tanári szakmai fejlesztés fókuszába.

Általánosságban elmondható, hogy a tanártovábbképzések témái valóban a napjainkban releváns területeket érintik: szaktudományos, didaktikai témákat, illetve a digitális tanulási technológiákhoz, az iskolai fejlesztés és az iskolamenedzsment területéhez kapcsolódó tartalmakat kínálnak.

A tanártovábbképzés jelenét és jövőjét vizsgáló tanulmányában Müller és Andreitz (2019) a 2010 óta tetten érhető változások ellenére arra hívja fel a figyelmet, hogy Ausztriában még mindig hiányzik az oktatási rendszer hosszú távú koncepciója, átfogó mesterterve, és ez pillanatnyilag jelentős mértékben befolyásolja a tanártovábbképzés mozgásterét is.

\section{Irodalom}

Andreitz, I., Müller, F. CH. \& Wieser, M. (2017). Die Bedeutung der Motivation für die Fort- und Weiterbildung von Lehrkräften. In Kreis, I. \& Unterköfler-Klatzer, D. (Eds.), Fortbildung Kompakt. Wissenschaftstheoretische und praktische Modelle zur wirksamen Lehrer/ innenfortbildung (pp. 103-118). StudienVerlag. 
Pedagógusképzés • 19(47), 2020/1-2.

BRG (2017). Bundesgesetzblatt für die Republik Österreich. 138. Bundesgesetz: Bildungsreformgesetz 2017. Änderung des Landeslehrerdienstrechtsgesetzes. https://www.ris.bka.gv.at/Dokumente/BgblAuth/BGBLA_2017_I_138/BGBLA_ 2017_I_138.pdf (2020. 06. 22.)

BUKK (2009). Bundesministerium für Unterricht, Kunst und Kultur (BMUKK) (2009): Schwerpunktsetzungen im Bereich der Fort- und Weiterbildung 20102013 an den Pädagogischen Hochschulen. Rundschreiben Nr. 22/2009. https://www.bmbwf.gv.at/Themen/schule/schulrecht/rs/19972017/2009_22.html (2020.07.04.)

BBF (2014). Bundesministerium für Bildung und Frauen (BMBF) (2014): Schwerpunktsetzungen im Bereich der Fort- und Weiterbildung 2014-2018 an den Pädagogischen Hochschulen. Rundschreiben Nr. 5/2014. https://www.bmbwf.gv.at/Themen/schule/schulrecht/rs/19972017/2014_05.html (2020.07.05.)

BBWF (2017). Bundesministerium Bildung, Wissenschaft und Forschung (BBWF) (2017): Bildungsreform 2017. Freiheit für die Schulen, Transparenz fürs System, Modellregionen für die gemeinsame Schule.

https://www.bmbwf.gv.at/Themen/schule/zrp/bilref.html (2020. 07. 13.)

DN (2013). Dienstrechts-Novelle 2013 - Pädagogischer Dienst (542/ME (XXIV. GP) www.parlament.gv.at (2020. 07. 11.)

Fischer, S. (2017). Zur Nachhaltigkeit von Lehrerweiterbildung in der Schweiz. (German), Report: Zeitschrift für Weiterbildungsforschung, 40(3), 241-259. DOI: $10.1007 / \mathrm{s} 40$ 955-017-0101-5

Fussangel, K., Rürup, M. \& Gräsel, C. (2016). Lehrerfortbildung als Unterstützungssystem. In Altrichter, H. \& Maag Merki, K. (Eds.), Handbuch Neue Steuerung im Schulsystem (pp. 361-384), Wiesbaden: Springer VS. DOI: 10.1007/9783-531-92 245-4

Göb, N. (2017). Professionalisierung durch Lehrerfortbildung: Wie wird der Lernprozess der Teilnehmenden unterstützt? DDS - Die Deutsche Schule (109/1), 927. https://www.waxmann.com/index.php? eID=download\&id_artikel=ART102 118\&uid=frei (2020. 04. 20.)

Jaschke, Z. (2016). Wirksamkeitsvermutungen in Bezug auf das Unterrichtshandeln bei Absolventen einer allgemeinpädagogischen Lehrerfortbildung. Eingegangen: 2. Februar 2016 / Angenommen: 10. Mai 2016 / Online publiziert: 9. Juni 2016 ( The Author(s) 2016. This article is available at SpringerLink with Open Access. ZFW DOI 10.1007/s40 955-016-0055-z 
Lipowsky, F. (2014). Theoretische Perspektiven und empirische Befunde zur Wirksamkeit von Lehrerfort- und -weiterbildung. In Terhart, E., Bennewitz, H., \& Rothland, M. (Eds.), Handbuch der Forschung zum Lehrerberuf (2. Auflage) (pp. 511-541). Waxmann.

Mayr, J. \& Neuweg, G. H. (2009). Lehrer/innen als zentrale Ressource im Bildungssystem: Rekrutierung und Qualifizierung. In Specht, W. (Ed.), Nationaler Bildungsbericht Österreich 2009, Band 2: Fokussierte Analysen bildungspolitischer Schwerpunktthemen (pp. 99-120). Graz: Leykam. https://www.bifie.at/wpcontent/uploads/2017/05/2009-06-16_NBB-Band2.pdf (2020. 07. 01.)

Mayr, J. \& Müller, F. H. (2010). Wovon hängt es ab, wie und wieviel sich Lehrerinnen und Lehrer fortbilden? In Schmich, J. \& Schreiner, C. (Eds.), TALIS 2008: Schule als Lernumfeld und Arbeitsplatz. Vertiefende Analysen aus österreichischer Perspektive (BIFIE-Report 4/2010) (pp. 11-25). Leykam.

https://www.researchgate.net/publication/287 640 788_Wovon_hangt_es_ab_wi e_und_wieviel_sich_Lehrerinnen_und_Lehrer_fortbilden (2020.07. 19.)

Müller, F. H. \& Andreitz, I. (2019). Gegenwart und Zukunft der LehrerInnenfortbildung in Österreich - ein kurzer Abriss. In Kastner, M., Donlic, J., Hanfstingl, B. \& Jaksche-Hoffman, E. (Eds.), (2019), Lernprozesse über die Lebensspanne Bildung erforschen, gestalten und nachhaltig fördern (pp. 53-67). Verlag Barbara Budrich. DOI: 10.2307/j.ctvpbnq3n.6

Müller, F. H., Kemethofer, D., Andreitz, I., Nachbaur, G. \& Soukup-Altrichter, K. (2019). Lehrerfortbildung und Lehrerweiterbildung. In Oberwimmer, K., Vogtenhuber, S., Lassnigg, L. \& Schreiner, C. (Eds.), Nationaler Bildungsbericht Österreich 2018, Band 1 Das Schulsystem im Spiegel von Daten und Indikatoren. Leykam. DOI: $10.17888 / n b b 2018-1.2$ Version 2 99-142 (2020. 04. 19.)

Nyikos, M. (2011). Tanárképzés és a tanári pálya Ausztriában. In Falus, I. (Ed.), Tanári pályaalkalmasság - kompetenciák - sztenderdek. Nemzetközi áttekintés (pp. 207-226). Líceum Kiadó.

Rechnungshof (2007). Lehrerfortbildung (Wirkungsbereich des Bundesministeriums für Bildung, Wissenschaft und Kultur). In Rechnungshof (Ed.), Bericht des Rechnungshofes (Reihe Bund 2007/04, Band 4 - Wiedervorlage von Bund 2006/01, 2006/03, 2006/05 (71-94). Wien.

https://www.rechnungshof.gv.at/rh/home/home_1/home_2/Taetigkeitsbericht_ 2006.pdf (2020. 07. 01.)

Rechnungshof (2017). Bericht des Rechnungshofes. Lehrpersonenfort- und -weiterbildung.

https://www.rechnungshof.gv.at/rh/home/home/Bund_Lehrpersonen_und_wei terbildung_2017_02_1.pdf (2020.04.19.) 
Pedagógusképzés • 19(47), 2020/1-2.

SchUG (1986). Schulunterrichtsgesetz.

http://www.jusline.at/Schulunterrichtsgesetz_(SchUG)_Langversion.html (2020. 07. 19.)

Virág, I. (2013). Tanártovábbképzés Ausztriában. In Falus, I. (Ed.), Pedagógustovábbképzés. Nemzetközi áttekintés (pp. 137-171). Líceum Kiadó.

Virág, I. (2018). A tanári pálya Ausztriában. In Ugrai J. \& Virág, I. (Eds.), Acta Universitatis de Carolo Eszterházy Nominatae Tom. XLI. Sectio Paedagogica. Tanulmányok a neveléstudomány köréből. (pp. 111-136.). Líceum Kiadó.

Zehetmeier, S. (2017). Theoretische und empirische Grundlagen für eine innovative und nachhaltige Lehrer/innenfortbildung. In Kreis, I. \& Unterköfler-Klatzer, D. (Eds.), Fortbildung Kompakt. Wissenschaftstheoretische und praktische Modelle zur wirksamen Lehrer/innenfortbildung (pp. 80-102). Studien Verlag.

Zehetmeier, S. (2019). Nachhaltige Wirkungen von Innovationen in der LehreInnenfortbildung. In Kastner, M., Donlic, J., Hanfstingl, B. \& Jaksche-Hoffman, E. (Eds.), Lernprozesse über die Lebensspanne Bildung erforschen, gestalten und nachhaltig fördern. (pp. 37-53). Verlag Barbara Budrich.

DOI: $10.2307 /$ j.ctvpbnq3n.5

\section{In-service Teacher Education in Austria in the 2010s}

The present paper aims at exploring the state of teachers' in-service professional development in Austria with respect to its reform in the 2010s. Through analysing primary sources, the study investigates in detail the training policy objectives and the targeted competences as compiled by professionals responsible for the reform processes. The content and form of the training courses realised in the designated period, the methods of quality assurance and the problems which still need to be resolved are discussed in the part based on the findings of secondary sources, which reflect on the reform of teachers' in-service professional development.

Keywords: Austria, teachers' in-service professional development, the reform of teachers' in-service professional development 